\title{
Function of ghrelin and ghrelin receptors in the network regulation of gastric motility
}

\author{
CHENG-GUANG YANG ${ }^{1}$, ZUO-FU LIAO ${ }^{1}$, WEN-CAI QIU ${ }^{2}$, JUN YAN ${ }^{2}$ and ZHI-GANG WANG ${ }^{2}$ \\ ${ }^{1}$ Department of General Surgery, The Affiliated Tongren Hospital of Medical School, Shanghai Jiaotong University, \\ Shanghai 200336; ${ }^{2}$ Department of General Surgery, The Affiliated Sixth Hospital of Medical School, \\ Shanghai Jiaotong University, Shanghai 200233, P.R. China
}

Received October 25, 2013; Accepted May 21, 2014

DOI: $10.3892 / \mathrm{mmr} .2014 .2571$

\begin{abstract}
Numerous previous studies have demonstrated that ghrelin promotes gastric motility when administered peripherally. This effect appears to be regulatory but not directly stimulatory, and therefore may involve a number of complex mechanisms. In the periphery, ghrelin may affect gastric motility through intercellular networks among interstitial cells of Cajal, myenteric nerve cells and smooth muscle cells. The aim of the present study was to investigate the effects and possible mechanisms underlying this hypothesis. The effects of ghrelin on the contraction force of gastric antrum smooth muscle strips of rats were studied in the presence or absence of carbachol (CCh), [D-Lys3]-GHRP-6, atropine, tetrodotoxin (TTX) and nimodipine in vitro. The expression of ghrelin receptors (GHS-Rs) on different cell types in gastric muscle layers was observed by means of immunofluorescence. Ghrelin enhanced smooth muscle strip contraction induced by $\mathrm{CCh}$, but when $\mathrm{CCh}$ was absent, this effect was eliminated. Atropine and nimodipine eradicated the muscle strip contraction enhanced by ghrelin, while [D-Lys3]-GHRP-6 was only able to partly block this effect and TTX had no effect on muscle strip contraction. It was identified that ghrelin had no effect on the contractive rhythm of the strips. GHS-R1s were located differentially depending on the cell type, including myenteric nerve cells, interstitial cells of Cajal and smooth muscle cells. In conclusion the present study demonstrated that ghrelin may act as an adjuvant to regulate gastric smooth muscle contraction induced by CCh through GHS-R1s, which are expressed on myenteric nerve cells, Cajal cells and smooth muscle cells. Ghrelin may exert its effects by influencing the functional status of different cell types in the gastric muscle
\end{abstract}

Correspondence to: Professor Zhi-Gang Wang, Department of General Surgery, The Affiliated Sixth Hospital of Medical School, Shanghai Jiaotong University, 600 Yishan Road, Shanghai 200233, P.R. China

E-mail: sh6zhq@163.com

Key words: ghrelin, ghrelin receptors, myenteric nerve cell, Cajal cell, smooth muscle cell, network layer to subsequently enhance the contractive effect of cholinergic neurotransmitters and enhance gastric motility.

\section{Introduction}

Ghrelin is a gastrointestinal hormone, which exerts its effects by interacting with ghrelin receptors (GHS-Rs) (1). Previous studies have demonstrated that ghrelin has a wide variety of biological functions (2-5), one of which is in promoting gastrointestinal motility. The administration of ghrelin via the central nervous system appears to have a pronounced effect on appetite and the motility of the gastrointestinal tract (6-7). Peripheral administration of ghrelin has also been demonstrated to enhance the motility of the gastrointestinal tract (8-10). The effects of ghrelin may be mediated by the activation of ghrelin receptors on the vagal nerve (5) and gastrointestinal enteric plexus (11). When the vagal nerve is severed, the central effects of ghrelin are eliminated (12). In vitro, the application of ghrelin alone, in the absence of carbachol (CCh), does not promote smooth muscle strip contraction $(13,14)$. It appears that ghrelin may promote gastric motility through a peripheral channel. This effect appears to be regulatory but not directly stimulatory, and therefore may involve a number of complex mechanisms (14).

As is well established, the network regulations of gastrointestinal motility mainly involve interstitial cells of Cajal (ICC), myenteric nerve cells and smooth muscle cells. Cajal cells generate slow waves of contraction and conduct them to adjacent smooth muscle cells to induce spontaneous rhythmic contractions $(15,16)$. Cajal cells have been consistently associated with adjacent smooth muscle cells and neurons in histological analysis studies of the gastrointestinal and urinary tract $(17,18)$.

At present, there are no explicit conclusions regarding the mechanisms and pathways involved in the effects of ghrelin on gastrointestinal motility. The present study aimed to examine the possible effects and mechanisms of ghrelin on gastric motility in terms of its interactions with the intercellular network among ICCs, myenteric nerve cells and smooth muscle cells of the stomach wall.

\section{Materials and methods}

Animals. All of the animal procedures were conducted according to the ethical guidelines of the ethics committee 
of Shanghai Jiaotong University (Shanghai, China). A total of 36 male Sprague-Dawley rats $(250 \pm 50 \mathrm{~g})$ were obtained from the Experimental Animal Center of the Shanghai Academia Sinica (Shanghai, China). The rats were housed in stainless steel cages at a controlled humidity (60-65\%) and temperature $\left(22 \pm 2^{\circ} \mathrm{C}\right)$ with a standard $12: 12 \mathrm{~h} \mathrm{light/dark}$ cycle.

Drugs and chemicals. Rat ghrelin, [D-Lys3]-GHRP-6 (an antagonist of GHS-R), atropine (an antagonist of M-type cholinergic receptor), carbamoylcholine chloride and nimodipine were obtained from Tocris Cookson (Bristol, UK), tetrodotoxin (TTX) was obtained from Sigma (St. Louis, MO, USA), goat anti-rat GHS-R1 (D-16) antibody, mouse anti-rat NF-H (H-5) antibody, mouse anti-rat a-actin antibody (1A4) antibody and rabbit anti-rat c-Kit antibody (C-19) were obtained from Santa Cruz Biotechnology, Inc. (Santa Cruz, CA, USA). fluorescein isothiocyanate (FITC)-conjugated goat anti-mouse and goat anti-rabbit secondary antibodies as well as tetramethylrhodamine (TRITC)-conjugated rabbit anti-goat secondary antibody were obtained from Jackson ImmunoResearch Laboratories, Inc. (West Grove, PA, USA).

Organ bath. The rats were sacrificed by cervical dislocation. The stomachs were immediately removed and placed in cold Krebs solution containing $121.5 \mathrm{mM} / 1 \mathrm{NaCl}, 4.7 \mathrm{mM} / 1 \mathrm{KCl}$, $2.5 \mathrm{mM} / 1 \mathrm{CaCl}_{2}, 1.2 \mathrm{mM} / 1 \mathrm{MgSO}_{4}, 1.2 \mathrm{mM} / 1 \mathrm{KH}_{2} \mathrm{PO}_{4}$, $25.0 \mathrm{mM} / 1 \mathrm{NaHCO}_{3}$ and $5.6 \mathrm{mM} / 1$ glucose (gassed with 95\% $\mathrm{O}_{2} / 5 \% \mathrm{CO}_{2}$ ), which was prepared according to previous methods $(14,19)$. Preparation of smooth muscle strips was performed using an Olympus BX41 microscope (Olympus, Tokyo, Japan; magnification, x10). The circular muscle strips (length, $10 \mathrm{~mm}$; width, $2 \mathrm{~mm}$ ), stripped of mucosa and submucosa, were suspended vertically in a $5 \mathrm{ml}$ organ bath chamber filled with Krebs solution. The organ bath chamber was gassed with $95 \% \mathrm{O}_{2} / 5 \% \mathrm{CO}_{2}$ and warmed to $37^{\circ} \mathrm{C}$. One end of the muscle strip was fixed to a hook at the bottom of the chamber while the other end was connected by a thread to an external isometric force transducer (Harvard Apparatus, Holliston, MA, USA) at the top. Figures of isometric tension obtained from the isometric force transducer were continuously recorded and stored on a computer by the SMUP-E biological signal processing system (Chengdu Equipment Factory, Chengdu, China), to transfer contraction signals into information, which is recorded and stored on a computer. The strips were stretched to a tension of $0.1 \mathrm{~g}$ and allowed to equilibrate for $40 \mathrm{~min}$. The buffer was changed every $10 \mathrm{~min}$. The measurements were conducted following $1 \mathrm{~h}$ of equilibration.

Effect of ghrelin on contraction amplitude and rhythm of smooth muscle strips in vitro. In the present study, 0.01, 0.1, 0.5 or $1.0 \mu \mathrm{mol} / 1$ ghrelin was administered to the strips in the presence or absence of $\mathrm{CCh}(50 \mathrm{nmol} / \mathrm{l} ; \mathrm{n}=6$, each condition). The effect of ghrelin on muscle strip contraction was expressed as the percent change from the mean of the three drug responses to $\mathrm{CCh}$, according to a previous study (5).

Effects of [D-Lys3]-GHRP-6, atropine, TTX and nimodipine on smooth muscle strips contraction induced by ghrelin and CCh in vitro. The smooth muscle strips were pretreated with $\mathrm{CCh}(50 \mathrm{nmol} / \mathrm{l})$ and $0.5 \mu \mathrm{mol} / 1$ ghrelin. Following this,
[D-Lys3]-GHRP-6 $(5 \mu \mathrm{mol} / 1)$, atropine $(0.5 \mu \mathrm{mol} / 1)$, TTX $(1 \mu \mathrm{mol} / \mathrm{l})$ and nimodipine $(5 \mu \mathrm{mol} / \mathrm{l})$ were administered to the strips, respectively ( $\mathrm{n}=6$, each group). Following each administration, the strips were flushed with Krebs solution three times and subjected to $30 \mathrm{~min}$ of equilibration. The effects of different experimental drugs on muscle strip contraction were expressed as the percent change from the mean of three drug responses to $\mathrm{CCh}$ combined with ghrelin.

Immunofluorescent staining. Fluorescent staining of GHS-R1s in the gastric antrum muscle layers was studied in the rats. The circular muscle strips were stripped of mucous and submucous layers, stretched to $150 \%$, placed on a platform and the tissue was subsequently fixed with $4^{\circ} \mathrm{C}$ acetone for $15 \mathrm{~min}$. The acetone was removed by washing with $1 \mathrm{x}$ phosphate-buffered saline. The muscle tissues were then incubated with $10 \%$ fetal bovine serum for $60 \mathrm{~min}$. Next, tissues were incubated with primary antibodies (dilution, 1:100) with $0.5 \%$ Triton X-100 at $4^{\circ} \mathrm{C}$ for two days, followed by secondary antibodies (1:200) conjugated with FITC or TRITC for $12 \mathrm{~h}$ the dark at room temperature. DAPI was used as a nuclear counterstain. Finally, the tissues were transferred from the platforms to glass slides and mounted with $50 \%$ glycerol. The slides were observed and scanned under a laser confocal microscope (FV-1000; Olympus, Tokyo, Japan).

GHS-RIs staining on gastric antrum muscle layer nerve cells. The muscle layer nerve cells were stained with goat anti-rat GHS-R1 (D-16) and mouse anti-rat NF-H (H-5) primary antibodies, followed by goat anti-mouse and rabbit anti-goat secondary antibodies conjugated with FITC and TRITC, respectively. Staining was performed in accordance with the aforementioned method. The GHS-R1 antibody (D-16) was used to label the GHS-R1s and the NF-H antibody (H-5), a neuron-specific marker, was used to label the nerve cells.

GHS-RIs staining of gastric antrum muscle layer Cajal cells. Muscle layer Cajal cells were stained with goat anti-rat GHS-R1 (D-16) and rabbit anti-rat c-Kit antibodies (C-19), followed by goat anti-rabbit and rabbit anti-goat secondary antibodies coupled with FITC and TRITC, respectively. The c-Kit antibody (C-19), a Cajal-specific marker, was used to label the Cajal cells.

GHS-RIs staining on cultured gastric antrum smooth muscle cells. Gastric antrum smooth muscle layers stripped of mucous and submucous layers were sheared into $1 \mathrm{~mm}^{2}$ pieces, cultured with Dulbecco's modified Eagle's medium (DMEM), subcultured for three passages and the cells were then fixed with acetone cooled to $4^{\circ} \mathrm{C}$ for $15 \mathrm{~min}$. The subsequent procedures of staining were performed in accordance with the abovementioned method. The smooth muscle cells were stained with goat anti-rat GHS-R1 (D-16) and mouse anti-rat $\alpha$-actin antibody (1A4), followed by goat anti-rabbit and rabbit anti-goat secondary antibodies coupled by with FITC and TRITC, respectively. The $\alpha$-actin antibody (1A4), a smooth muscle-specific marker, was used to label the smooth muscle cells.

Statistical analysis. Values are expressed as the mean \pm standard error of the mean. The data were analyzed using Origin 8.0 software (OriginLab Corp., Northampton, MA, USA). 
Photoshop 8.0.1 software (Adobe Systems Inc., Mountain View, CA, USA) was used to produce the figures. The data recordings were evaluated by one way analysis of variance followed by Dunnett's test. $\mathrm{P}<0.05$ was considered to indicate a statistically significant difference between values.

\section{Results}

Effect of ghrelin on the contraction amplitude and rhythm of smooth muscle strips in vitro. When CCh was absent, ghrelin had no effect on the contraction amplitude and rhythm of the smooth muscle strips. However, in the presence of CCh $(50 \mathrm{nmol} / \mathrm{l})$, ghrelin $(0.01,0.1,0.5$ or $1.0 \mu \mathrm{mol} / \mathrm{l})$ dose-dependently increased the contraction amplitude of the muscle strips. When compared with the response to $\mathrm{CCh}$ alone, at ghrelin concentrations of $0.01,0.1,0.5$ or $1.0 \mu \mathrm{mol} / 1$, the contractile amplitudes were $104.4 \pm 2.6,147.5 \pm 3.6,185.2 \pm 5.1$ and $216.4 \pm 6.3 \%$, respectively $(\mathrm{P}<0.01$, except for the $0.01 \mu \mathrm{mol} / 1$ ghrelin group; Table I); however, the contraction rhythm remained unchanged.

Effects of different experimental drugs on smooth muscle strip contraction induced by ghrelin and CCh in vitro. In the presence of CCh $(50 \mathrm{nmol} / \mathrm{l})$ combined with ghrelin $(0.1 \mu \mathrm{mol} / \mathrm{l})$, [D-Lys3]-GHRP-6 (5 $\mu \mathrm{mol} / 1)$, atropine $(0.5 \mu \mathrm{mol} / \mathrm{l})$, TTX (1 $\mu \mathrm{mol} / 1)$ and nimodipine $(5 \mu \mathrm{mol} / 1)$ were administered to the strips and when compared with the response to $\mathrm{CCh}$ combined with ghrelin, the contractile amplitudes were $76.4 \pm 2.3,4.5 \pm 1.2,98.7 \pm 2.9$ and $5.2 \pm 1.6 \%$, respectively $(\mathrm{P}<0.01$, except for the TTX group; Table II). Compared with the response to $\mathrm{CCh}$ alone, the contractile amplitudes were $112.7 \pm 3.6,6.6 \pm 1.7,144.9 \pm 3.8$ and $7.6 \pm 2.1 \%$, respectively ( $\mathrm{P}<0.01$; Table III).

Fluorescent stainings of gastric antrum nerve cells, Cajal cells and smooth muscle cells. Immunofluorescent staining indicated that in the gastric antrum muscle layer nerve cells, GHS-R1s (red fluorescence) were mainly located on the cytomembranes and cytoplasms of these cells, and GHS-R1s were found on the cellular bodies (Fig. 1A and 1C, big white arrows) and neural fibers (Fig. 1A and 1C, small white arrows) of both types. The fluorescence intensity was higher when compared with that of the Cajal cells and smooth muscle cells (data not shown). NF-H staining was used to label the nerve cells and, as Fig. 1B (green fluorescent arrows) shows, these nerve cells were those cells in Fig. 1A that expressed GHS-R1s and were in the same locations.

In the Cajal cells, GHS-R1s (red fluorescence) was also identified on the cytomembranes and cytoplasm, and the fluorescence intensity was higher on the cytomembranes (Fig. 2A and 2C). However, no GHS-R1s were found on the long cell protrusions, while it was noted that there were numerous cell protrusions crossing each other (Fig. 2B and 2C, green fluorescence). c-kit staining was performed to label the Cajal cells. Fig. 2B (green fluorescence arrows) shows that these Cajal cells were those that expressed GHS-R1s (Fig. 2A) and were in the same locations.

In the cultured smooth muscle cells, GHS-R1s (red fluorescence) were found mainly in the cytoplasm of these cells, while the fluorescence intensity was lower on the cytomembranes (Fig. 3A and 3C). However, granules of intensive red
Table I. Changes in contractile amplitude with different concentrations of Ghrelin in the presence of Cch $(50 \mathrm{nmol} / \mathrm{l})$.

\begin{tabular}{lc}
\hline $\begin{array}{l}\text { Ghrelin } \\
(\mu \mathrm{mmol} / \mathrm{l})\end{array}$ & $\begin{array}{c}\text { Contractile } \\
\text { amplitude }(\%)\end{array}$ \\
\hline 0 & 100 \\
0.01 & $104.4 \pm 2.6$ \\
0.1 & $147.5 \pm 3.6$ \\
0.5 & $185.2 \pm 5.1$ \\
1.0 & $216.4 \pm 6.3$
\end{tabular}

Contractile amplitude induced by $\mathrm{Cch}$ alone is $100 \%$. Percentages indicate the percentage change in contractile amplitude. Cch, carbachol.

Table II. Changes in contractile amplitude by different drugs in the presence of Cch $(50 \mathrm{nmol} / \mathrm{l})$ and ghrelin $(0.1 \mu \mathrm{mol} / \mathrm{l})$.

\begin{tabular}{lr}
\hline Drug & $\begin{array}{c}\text { Contractile } \\
\text { amplitude }(\%)\end{array}$ \\
\hline None & 100 \\
[D-Lys3]-GHRP-6 $(5 \mu \mathrm{mol} / \mathrm{l})$ & $76.4 \pm 2.3$ \\
Atropine $(0.5 \mu \mathrm{mol} / 1)$ & $4.5 \pm 1.2$ \\
Tetrodotoxin $(1 \mu \mathrm{mol} / \mathrm{l})$ & $98.7 \pm 2.9$ \\
Nimodipine $(5 \mu \mathrm{mol} / \mathrm{l})$ & $5.2 \pm 1.6$
\end{tabular}

Contractile amplitude induced by $\mathrm{Cch}$ and ghrelin is $100 \%$. Percentages indicate the mean \pm standard error of the mean percentage change in contractile amplitude. Cch, carbachol.

Table III. Changes in contractile amplitude by different drugs in the presence of $\mathrm{Cch}(50 \mathrm{nmol} / \mathrm{l})$.

\begin{tabular}{lr}
\hline Drug & $\begin{array}{c}\text { Contractile } \\
\text { amplitude }(\%)\end{array}$ \\
\hline None & 100 \\
Ghrelin $(0.1 \mu \mathrm{mol} / \mathrm{l})$ & $147.5 \pm 3.6$ \\
[D-Lys3]-GHRP-6 $(5 \mu \mathrm{mol} / \mathrm{l})$ & $112.7 \pm 3.6$ \\
Atropine $(0.5 \mu \mathrm{mol} / 1)$ & $6.6 \pm 1.7$ \\
Tetrodotoxin $(1 \mu \mathrm{mol} / 1)$ & $144.9 \pm 3.8$ \\
Nimodipine $(5 \mu \mathrm{mol} / \mathrm{l})$ & $7.6 \pm 2.1$ \\
\hline
\end{tabular}

Contractile amplitude induced by $\mathrm{Cch}$ is $100 \%$. Percentages indicate the mean \pm standard error of the mean percentage change in contractile amplitude. Cch, carbachol.

fluorescence were also found in the cell nuclei (Fig. 3A and 3C). Alpha-actin staining was perfotmed to label the smooth muscle cells. Fig. 3B (green fluorescence arrows) shows that these smooth muscle cells were those that expressed GHS-R1s (Fig. 3A) and were in the same locations. 

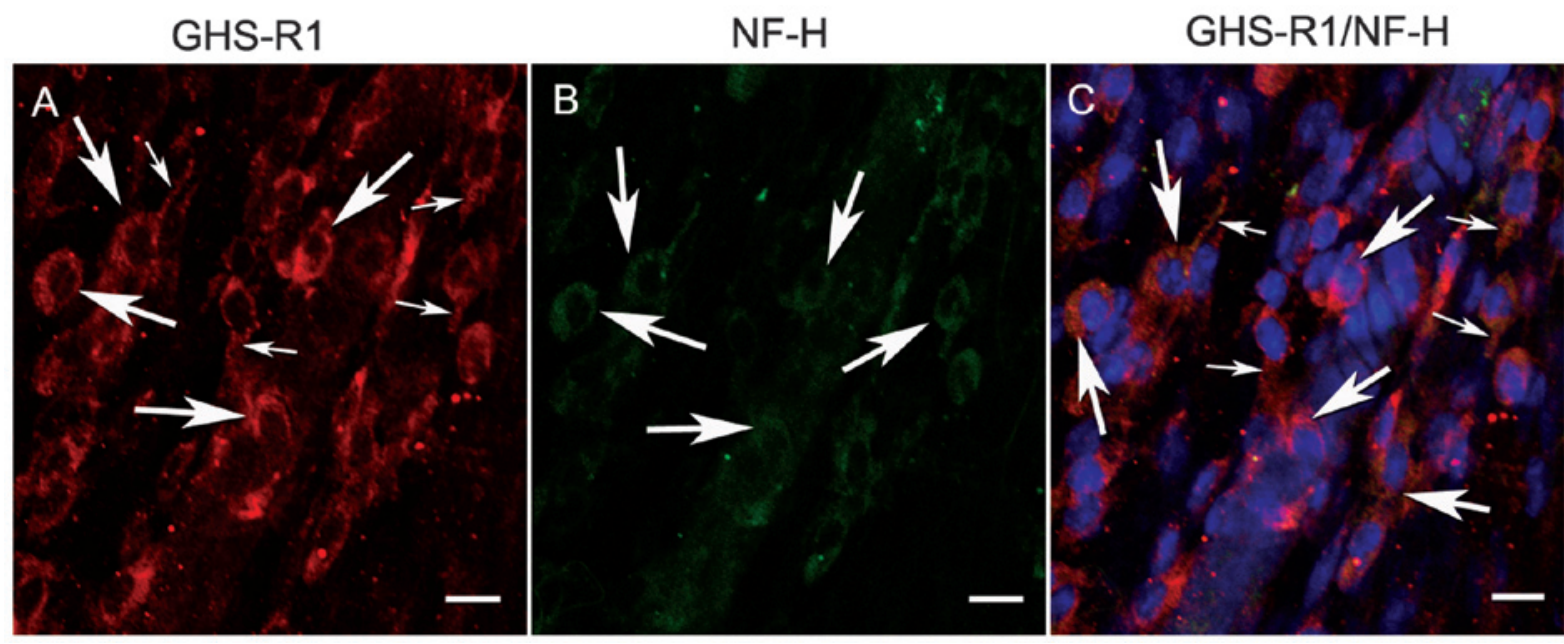

Figure 1. GHS-R1s and NF-H immunofluorescent staining in gastric antrum nerve cells. (A) GHS-R1s staining (red fluorescence; big arrows indicate cellular bodies and small arrows indicate neural fibers); (B) NF-H staining (green fluorescence, arrows); (C) GHS-R1s/NF-H staining (merged image fluorescence, big arrows indicate cellular bodies and small arrows indicate neural fibers). Cell nuclei, DAPI staining. Scale bar, $15 \mu \mathrm{m}$ (magnification, x40). GHS-Rs, ghrelin receptors; NF-H, neurofilament heavy polypeptide.

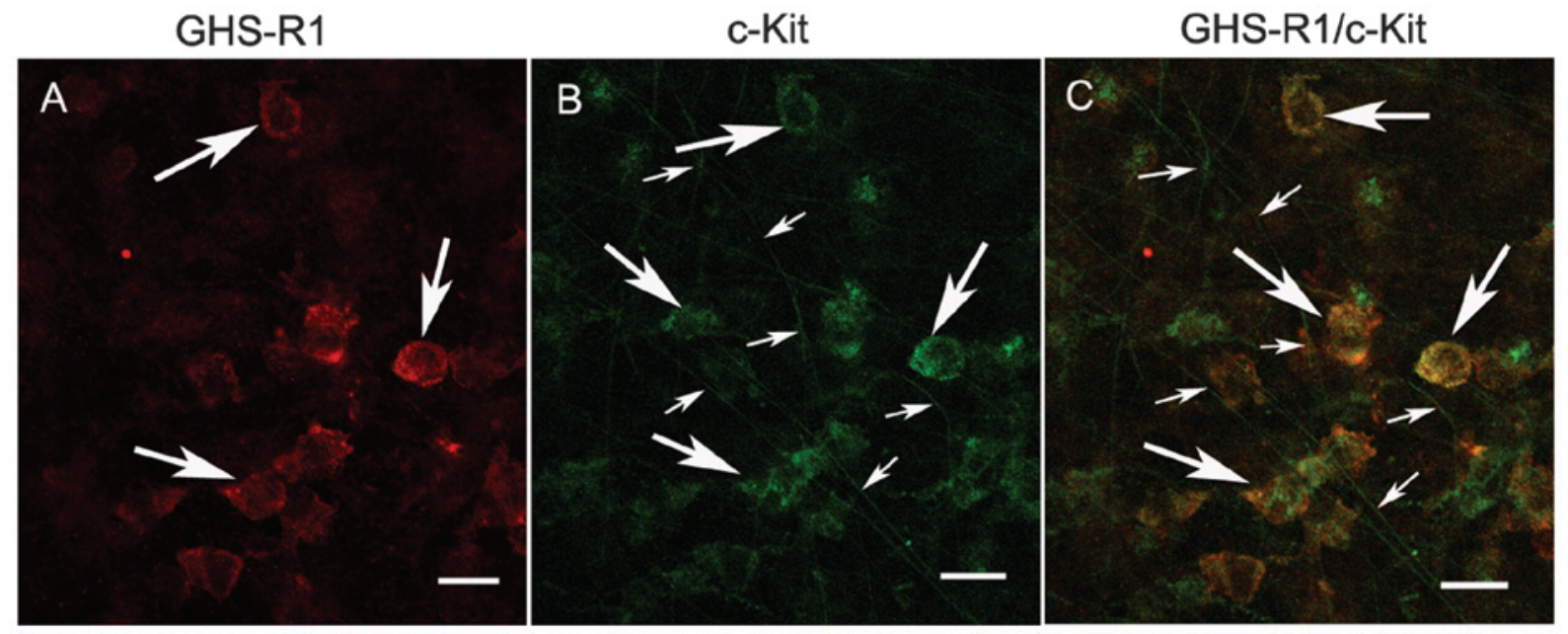

Figure 2. GHS-R1s and c-Kit immunofluorescent staining in gastric antrum Cajal cells. (A) GHS-R1s staining (red fluorescence, arrows); (B) c-Kit staining (green fluorescence, big/small arrows); (C) GHS-R1s/c-Kit staining (merged image fluorescence, big arrows). Scale bar, $20 \mu \mathrm{m}$ (magnification, x40). GHS-Rs, ghrelin receptors.
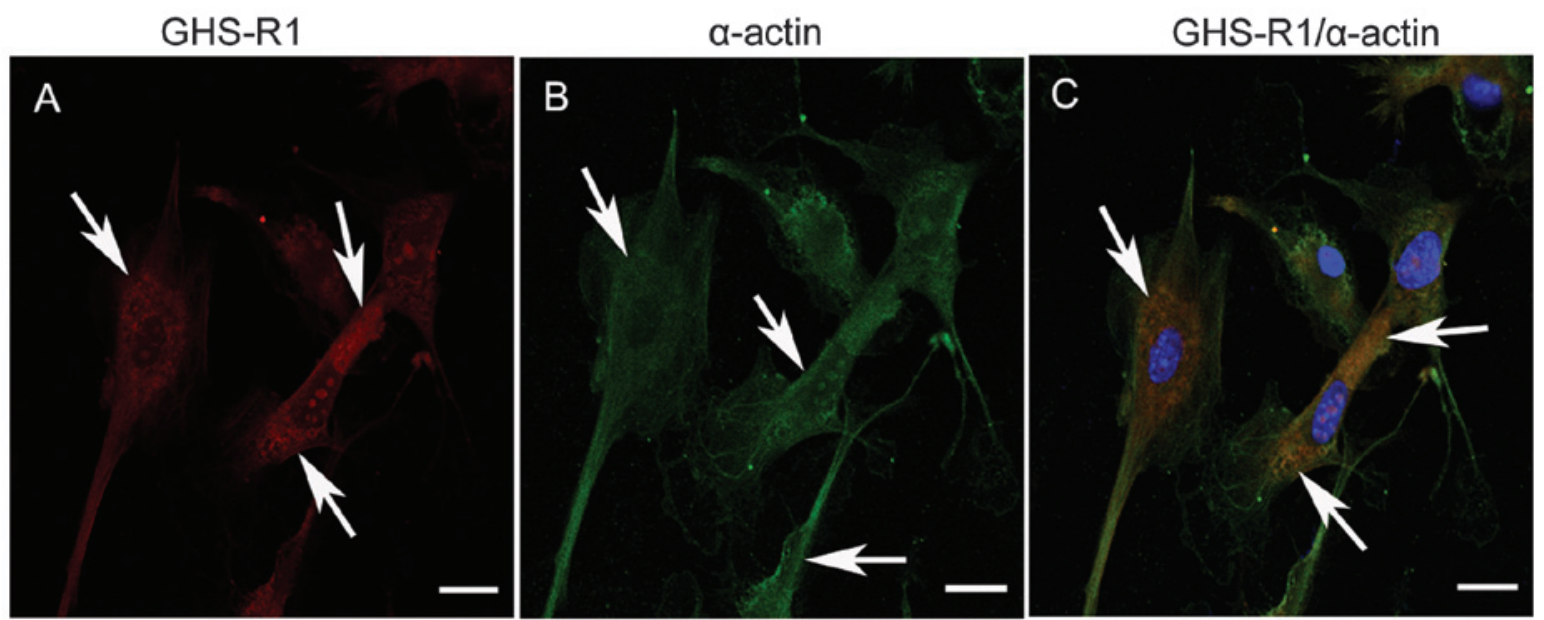

Figure 3. GHS-R1s and $\alpha$-actin immunofluorescent staining in cultured smooth muscle cells. (A) GHS-R1s staining (red fluorescence, arrows); (B) $\alpha$-actin staining (green fluorescence, arrows); (C) GHS-R1s/ $\alpha$-actin staining (merged image fluorescence, arrows). Cell nuclei, DAPI staining. Scale bar, $15 \mu \mathrm{m}$ (magnification, x40). GHS-Rs, ghrelin receptors. 


\section{Discussion}

Ghrelin has a pronounced effect on the motility of the gastrointestinal tract through its interactions with the central nervous system $(6,20)$. These effects are mediated through the expression of GH-Rs on the vagal nerve (21), as demonstrated by evidence showing that when the vagal nerve is severed, these effects are eliminated (12).

The peripheral administration of ghrelin also enhances the motility of the gastrointestinal tract if administered through peripheral channels $(11,22)$. The peripheral effects of ghrelin may be caused by the activation of GHS-Rs on the vagal nerve (5), gastrointestinal enteric plexus (23) or other types of cells.

A previous study by our group $(24,19)$ demonstrated that ghrelin was not able to induce a direct contractile response in vitro, but enhanced the contractile amplitudes of the smooth muscle strips induced by electrical field stimulation (EFS) or by $\mathrm{CCh}$ (13), which were in accordance with results previously obtained $(13,19)$. These phenomena suggested that the role of ghrelin may be that of an adjuvant, and that its ability to promote muscle strip contraction may rely on nerve impulses, neurotransmitter release or changes in membrane potential. This effect was regulatory but not directly stimulated, and therefore, may involve a number of complex mechanisms.

In the present study, different concentrations of ghrelin dose-dependently promoted the contraction of the strips in the presence of CCh. It was identified that the ghrelin at $0.1 \mu \mathrm{mol} / 1$ may be moderately stimulatory. In vitro, a 50 -fold or higher ghrelin concentration of that present under physiological conditions was required to promote smooth muscle strip contraction (27), which may be the result of a gradual decrease in concentration from the organ bath chamber to target cells, delayed diffusion of the experimental drug (14) or other mechanisms that remain elusive.

As it is well established, ICCs are considered as pacemaker cells that elicit spontaneous rhythmic electric activity termed 'slow waves' or 'basic electrical rhythm' in the gastrointestinal tract $(16,19)$. In the present study, it was identified that ghrelin had no effect on the contractive rhythm of the strips, even when the concentration of ghrelin was increased gradually. These results suggested that ghrelin may have had a minimal or no effect on the excitement conduction of Cajal cells. It may be possible that ghrelin does not target Cajal cells, or ghrelin may adjust the other functional status of Cajal cells, including cell excitability and cell survival, and require further investigation.

In the present study, the GHS-R antagonist ([D-lys3]-GHRP-6) inhibited the effect mediated by ghrelin in vitro experiments, but was not able to block this effect completely. Edholm et al (11) found that [D-lys3]-GHRP-6 had weaker antagonistic activity and a 100-fold excess of the antagonist was required to completely block the effect of ghrelin. This evidence may explain why [D-Lys3]-GHRP-6 only partly eliminated the muscle strip contraction enhanced by ghrelin. Subsequently, a distinct inhibitory effect was observed with increasing concentrations of [D-Lys3]-GHRP-6, which suggested that ghrelin exerted its effect through functional interaction with GHS-Rs, as it was previous reported that ghrelin was identified as an endogenous ligand for the former orphan receptor GHS-R1 (25). Atropine is a muscarinic receptor antagonist, which blocks muscarinic receptors. In the present study, the effect mediated by $\mathrm{CCh}$ and ghrelin was eliminated completely, so it was hypothesized that the target of ghrelin was possibly a component in the signaling pathway of cholinergic neurotransmitter signaling, downstream and upstream of the muscarinic receptor, and the role of ghrelin was to amplify the signal intensity. TTX is typically a sodium ion channel blocker, which selectively blocks voltage-dependent sodium channels, blocking the generation of action potentials and subsequently inhibiting neuromuscular excitement conduction. In the present study, TTX did not affect the contractile effect mediated by ghrelin and CCh, suggesting that as long as the neurotransmitter (acetylcholine) was present, ghrelin exerted its effects, despite the fact there was no neural excitation. It is possible that the target of ghrelin is a component of neuromuscular synapses or downstream synapses, or ghrelin may only adjust the functional status of nerve cells upstream synapses. Further studies are required to clarify the underlying mechanism of this effect. Nimodipine is a 1,4-dihydropyridine calcium channel blocker, which acts primarily on smooth muscle cells by stabilizing voltage-gated L-type calcium channels in their inactive conformation (28). By inhibiting the influx of calcium in smooth muscle cells, nimodipine prevents calcium-dependent smooth muscle contraction. It was identified that the effect mediated by $\mathrm{CCh}$ and ghrelin was eliminated completely by nimodipine. Therefore, it was hypothesized that ghrelin may exert its effects on gastric motility by relying on the active L-type calcium channels, which also regulates the cholinergic neurotransmitter signaling pathway.

By analyzing the effects following the administration of different drugs to the strips pre-treated with $\mathrm{CCh}$ and ghrelin, it was hypothesized that ghrelin may act on the signaling pathway of the cholinergic neurotransmitter and that ghrelin does not act independently, nor does it activate any specific point in the cholinergic neurotransmitter signaling pathway. Rather, the role of ghrelin was to amplify the signal intensity and ghrelin may adjust the functional status of upstream nerve cell synapses or Cajal cells and smooth cells downstream synapses. Further studies are required to clarify the mechanisms involved.

Ghrelin exerts its effects by activating GHS-Rs in central or peripheral tissues (5), and was identified as an endogenous ligand for the former orphan receptor GHS-R1a (25). At present, two types of GHS-R have been identified and designated receptors $1 \mathrm{a}$ and $\mathrm{lb}(1,26)$. GHS-R $1 \mathrm{a}$ is a 366 amino acid protein with seven transmembrane regions and a molecular mass of $\sim 41 \mathrm{kDa}$; GHS-R 1b is a 289 amino acid protein with only five transmembrane regions, which is widespread in numerous tissues; however, its significance remains to be determined (27). GHS-R1 (D-16) primary antibody combines with GHSR1a and GHSR1b. In the present study, immunofluorescent staining indicated that GHS-R1s were mainly located on the cytomembranes and cytoplasms of the nerve cells in the gastric plexus, and GHS-R1s were found on both the cellular bodies and neural fibers. Furthermore, the fluorescence intensity was higher when compared with that of Cajal cells and smooth muscle cells. These data morphologically supported the hypothesis that ghrelin acts through nerve cells in the gastrointestinal plexus $(29,30)$. These phenomena suggested that ghrelin may predominantly exert its effect by interacting with the nerve cells in the gastric antrum muscle layer. It may be possible that acylated ghrelin induces neuroendocrine actions 
by binding to the GHS-R1a, or non-acylated ghrelin exerts certain non-endocrine actions by binding to different GHS-R subtypes $(31,32)$. GHS-R1s were also found on the cytomembranes and cytoplasms of Cajal cells, and were mainly located on the cytomembranes, but no GHS-R1s were found on the long cell protrusions. In accordance with the effect of ghrelin discussed above, it was hypothesized that ghrelin may adjust the functional status of Cajal cell bodies through GHS-R1s, which may be of the GHS-R1a, GHS-R1b or other GHS-R subtypes. In cultured smooth muscle cells, GHS-R1s were mainly found in the cytoplasm and the fluorescence intensity was lower on the cytomembrane; however, granules of intensive red fluorescence were also found in the cell nucleus. Ghrelin may adjust the functional status of smooth muscle cells to enhance the effect of cholinergic neurotransmitters through GHS-R1s.

In conclusion, ghrelin may act as an adjuvant to regulate gastric smooth muscle contraction induced by cholinergic neurotransmitters (CCh) through GHS-R1s, which are expressed on myenteric nerve cells, interstitial cells of Cajal and smooth muscle cells. In different types of cells, ghrelin may have variable functional roles through the differential expression of GHS-R subtypes. Ghrelin may affect the excitation of myenteric nerve cells to release more cholinergic neurotransmitters by adjusting the functional status of smooth muscle cells to enhance the contractive effect of cholinergic neurotransmitters, or by adjusting the functional status of Cajal cells to promote the excitation conduction from Cajal to smooth muscle cells. Further studies are required to clarify the possible mechanisms underlying this effect.

\section{References}

1. van der Lely AJ, Tschöp M, Heiman ML and Ghigo E: Biological, physiological, pathophysiological, and pharmacological aspects of ghrelin. Endocr Rev 25: 426-457, 2004.

2. Arakawa M, Suzuki H, Minegishi Y, et al: Enhanced ghrelin expression and subsequent acid secretion in mice with genetic $\mathrm{H}(2)$-receptor knockout. J Gastroenterol 42: 711-718, 2007.

3. Asakawa A, Inui A, Fujimiya M, et al: Stomach regulates energy balance via acylated ghrelin and desacyl ghrelin. Gut 54: 18-24, 2005.

4. Nagaya $\mathrm{N}$ and Kangawa K: Ghrelin, a novel growth hormone-releasing peptide, in the treatment of chronic heart failure. Regul Pept 114: 71-77, 2003.

5. Fujino K, Inui A, Asakawa A, et al: Ghrelin induces fasted motor activity of the gastrointestinal tract in conscious fed rats. J Physiol 550: 227-240, 2003

6. Kamiji MM, Troncon LE, Suen VM and de Oliveira RB: Gastrointestinal transit, appetite, and energy balance in gastrectomized patients. Am J Clin Nutr 89: 231-239, 2009.

7. Kobashi M, Yanagihara M, Fujita M, et al: Fourth ventricular administration of ghrelin induces relaxation of the proximal stomach in the rat. Am J Physiol Regul Integr Comp Physiol 296 R217-R223, 2009.

8. Tack J, Depoortere I, Bisschops R, et al: Influence of ghrelin on interdigestive gastrointestinal motility in humans. Gut 55 : 327-333, 2006

9. Taniguchi $\mathrm{H}$, Ariga $\mathrm{H}$, Zheng J, et al: Effects of ghrelin on interdigestive contractions of the rat gastrointestinal tract. World J Gastroenterol 14: 6299-6302, 2008.

10. Kobelt P, Tebbe JJ, Tjandra I, et al: CCK inhibits the orexigenic effect of peripheral ghrelin. Am J Physiol Regul Integr Comp Physiol 288: R751-R758, 2005.
11. Edholm T, Levin F, Hellström PM and Schmidt PT: Ghrelin stimulates motility in the small intestine of rats through intrinsic cholinergic neurons. Regul Pept 121: 25-30, 2004.

12. Kamiji MM, Troncon LE, Antunes-Rodrigues J, et al: Ghrelin and PYY(3-36) in gastrectomized and vagotomized patients: relations with appetite, energy intake and resting energy expenditure. Eur J Clin Nutr 64: 845-852, 2010.

13. Qiu WC, Wang ZG, Wang WG, et al: Therapeutic effects of ghrelin and growth hormone releasing peptide 6 on gastroparesis in streptozotocin-induced diabetic guinea pigs in vivo and in vitro. Chinese Med J (Engl) 121:1183-1188, 2008.

14. Yang CG, Qiu WC, Wang ZG, Yu S, Yan J and Zheng Q: Down-regulation of ghrelin receptors in the small intestine delays small intestinal transit in vagotomized rats. Mol Med Rep 4: 1061-1065, 2011.

15. Huizinga JD, Thuneberg L, Klüppel M, et al: W/kit gene required for interstitial cells of Cajal and for intestinal pacemaker activity. Nature 373: 347-349, 1995.

16. Koh SD, Sansers KM and Ward SM: Spontaneous electrical rhythmicity in cultured interstitial cells of Cajal from the murine small intestine. J Physiol 513: 203-213, 1998.

17. McCloskey KD: Interstitial cells in the urinary bladder - localization and function. Neurourol Urodyn 29: 82-87, 2010.

18. Ward SM and Sanders KM: Involvement of intramuscular interstitial cells of Cajal in neuroeffector transmission in the gastrointestinal tract. J Physiol 576: 675-682, 2006.

19. Yang CG, Wang WG, Yan J, Fei J, Wang ZG and Zheng Q: Gastric motility in ghrelin receptor knockout mice. Mol Med Rep 7: 83-88, 2013.

20. Kobashi M, Yanagihara M, Fujita M, et al: Fourth ventricular administration of ghrelin induces relaxation of the proximal stomach in the rat. Am J Physiol Regul Integr Comp Physiol 296: R217-R223, 2009.

21. Ammori JB, Zhang WZ, Li JY, et al: Effects of ghrelin on neuronal survival in cells derived from dorsal motor nucleus of the vagus. Surgery 144: 159-167, 2008.

22. Kobelt P, Tebbe JJ, Tjandra I, et al: CCK inhibits the orexigenic effect of peripheral ghrelin. Am J Physiol Regul Integr Comp Physiol 288: R751-R758, 2005.

23. Murakami N, Hayashida T, Kuroiwa T, et al: Role for central ghrelin in food intake and secretion profile of stomach ghrelin in rats. J Endocrinol 174: 283-288, 2002.

24. Bassil AK, Dass NB and Sanger GJ: The prokinetic-like activity of ghrelin in rat isolated stomach is mediated via cholinergic and tachykininergic motor neurones. Eur J Pharmacol 544: 146-152, 2006.

25. Kojima M, Hosoda H, Date Y, et al: Ghrelin is a growth-hormone-releasing acylated peptide from stomach. Nature 402: 656-660, 1999.

26. McKee KK, Palyha OC, Feighner SD, et al: Molecular analysis of rat pituitary and hypothalamic growth hormone secretagogue receptors. Mol Endocrinol 11: 415-423, 1997.

27. Gnanapavan S, Kola B, Bustin SA, et al: The tissue distribution of the mRNA of ghrelin and subtypes of its receptor, GHS-R, in humans. J Clin Endocrinol Metab 87: 2988, 2002.

28. Wang D, Grillner S and Wallén P: Calcium dynamics during NMDA-induced membrane potential oscillations in lamprey spinal neurons-contribution of L-type calcium channels. J Physiol 91: 2509-2521, 2013.

29. Kitazawa T, De Smet B, Verbeke K, et al: Gastric motor effects of peptide and non-peptide ghrelin agonists in mice in vivo and in vitro. Gut 54: 1078-1084, 2005.

30. Depoortere I, De Winter B, Thijs T, et al: Comparison of the gastroprokinetic effects of ghrelin, GHRP-6 and motilin in rats in vivo and in vitro. Eur J Pharmacol 515: 160-168, 2005.

31. Date Y, Kojima M, Hosoda H, et al: Ghrelin, a novel growth hormone-releasing acylated peptide, is synthesized in a distinct endocrine cell type in the gastrointestinal tracts of rats and humans. Endocrinology 141: 4255-4261, 2000.

32. Cassoni $\mathrm{P}$, Papotti $\mathrm{M}$, Ghè $\mathrm{C}$, et al: Identification, characterization, and biological activity of specific receptors for natural (ghrelin) and synthetic growth hormone secretagogues and analogs in human breast carcinomas and cell lines. J Clin Endocrinol Metab 86: 1738-1745, 2001. 